\title{
Penerapan Aplikasi Presensi Siswa Menggunakan QR Code di SMAN 17 Surabaya
}

\author{
Endang Restuningsih \\ SMAN 17 Surabaya \\ Email : restu.eren23@gmail.com
}

\begin{abstract}
Teaching and learning activities in schools usually begin with the presence of student attendance first. SMAN 17 Surabaya is one of the schools that still uses student attendance manually and is considered less effective, because the manual recapitulation process takes quite a long time. Presence using an android smartphone and QR Code can be used to help the process of good presence and recapitulation is fast. Making a student presence application using an android smartphone and $Q R$ Code is built from a combination of several free Google products that are used free of charge, namely: Google Sheets, Google Apps Script, Google Sites, App Inventor, and Android. The features in the application are built among others, managing student data, doing attendance, and recapping student attendance in real time.
\end{abstract}

Keywords: QR Code, Android, Attendance

\begin{abstract}
Untuk Kegiatan belajar mengajar di sekolah biasanya diawali dengan presensi kehadiran siswa terlebih dahulu. SMAN 17 Surabaya adalah salah satu sekolah yang masih menggunakan presensi siswa secara manual dan dinilai kurang efektif, karena proses rekapitulasi manual membutuhkan ketelitian dan waktu cukup lama. Presensi menggunakan smartphone android dan QR Code bisa dimanfaatkan untuk membantu proses presensi yang baik dan rekapitulasi yang cepat. Pembuatan aplikasi presensi siswa menggunakan smartphone android dan QR Code ini dibangun dari gabungan beberapa produk Google yang bebas digunakan secara gratis yaitu : Google Sheet, Google App Script, Google Sites, App Inventor, dan Smartphone Android. Fitur dalam aplikasi yang dibangun antara lain, mengelola data siswa, melakukan presensi, dan merekap presensi siswa secara realtime.
\end{abstract}

Keywords: QR Code, Android, Presensi

\section{Pendahuluan}

Presensi atau pencatatan kehadiran siswa termasuk salah satu hal penting dalam kegiatan belajar mengajar di sekolah, karena kehadiran juga ikut menentukan seorang siswa layak naik kelas atau tidak ke tingkat berikutnya. Masalah yang terjadi dalam sistem yang telah diterapkan saat ini di SMA Negeri 17 Surabaya terletak pada pengumpulan data kehadiran siswa, dimana sistem presensi yang berjalan masih banyak di lakukan secara manual dengan cara mengambil buku kehadiran setiap kelas yang sudah diisi oleh pengurus kelas masing-masing setiap hari untuk direkap yang membutuhkan waktu cukup lama, kadang juga buku kehadiran kelas bisa saja hilang sehingga bisa menyulitkan guru bimbingan konseling jika ada salah satu siswa bermasalah dalam hal kehadiran yang melebihi batas ketentuan sekolah dan data kehadiran tersebut digunakan sebagai data pendukung utama (Rachman Arief, 2017).

Penggunaan aplikasi presensi online berbasis android dan QR Code ini merupakan salah satu cara yang bisa diimplementasikan untuk mengatasi permasalahan, membantu proses presensi yang baik dan rekapitulasi yang cepat. Pengguna sekolah atau guru tidak perlu lagi melakukan rekap kehadiran semua siswa, pengguna bisa mengetahui hasil rekap presensi secara langsung atau realtime dan melakukan deteksi dini pada siswa yang sering tidak hadir di sekolah untuk penanganan lebih lanjut. Untuk wali murid bisa memonitoring kehadiran siswa tiap hari dimana saja dan kapan saja menggunakan smartphone atau komputer dengan terhubung dengan jaringan internet.

Semakin berkembangnya penggunaan smartphone saat ini telah banyak diciptakan aplikasi yang bermanfaat dan memudahkan pekerjaan manusia. Google mempunyai banyak produk yang bisa dimanfaatkan secara bebas untuk keperluan pendidikan dan bisa digunakan secara gratis. Aplikasi presensi siswa menggunakan android dan QR Code yang dibuat ini menggunakan gabungan 4 produk Google yaitu : Sheet, Sites, Apps Script dan App Inventor untuk antar muka pada android. Tujuan dari 
pembuatan aplikasi ini adalah untuk memberikan solusi yang efektif dalam pencatatan dan perekapan presensi siswa di sekolah serta penggunaan teknologi yang murah dan gratis.

Permasalahan dalam hal kemudahan dan kecepatan inilah yang mendorong pemikiran membuat aplikasi presensi online menggunakan android dan QR Code yang dapat digunakan secara cepat serta mudah digunakan. Produk-produk Google terutama perangkat lunak produktifitas daring (dalam jaringan) yang digunakan untuk membuat aplikasi ini sebelumnya sudah banyak digunakan diseluruh dunia dalam bidang pendidikan atau bidang lainnya, serta tidak ada keraguan dalam menggunakannya (I. Cahyani, 2016). Aplikasi bisa diakses melalui berbagai perangkat yang tersambung dengan jaringan internet, misal : Smartphone, Tablet, Laptop, dan Personal Computer.

\section{Tinjauan Pustaka}

\subsection{QR Code}

Adalah jenis barcode yang berbentuk dua dimensi yang dikembangkan oleh Denso Wave, sebuah devisi Denso Corporation, sebuah perudahaan di Jepang, yang dipublikasikan pada tahun 1994 (Ching-yin law and Simon so, 2010). QR Code adalah image berupa matriks dua dimensi yang memiliki kemampuan untuk menyimpan data didalamnya. QR Code merupakan evolusi dari kode batang (barcode). Barcode merupakan sebuah symbol penandaan objek nyata yang terbuat dari pola batangbatang hitam dan putih agar mudah untuk dikenali komputer contoh sebuah QR Code dapat dilihat pada gambar 1 .

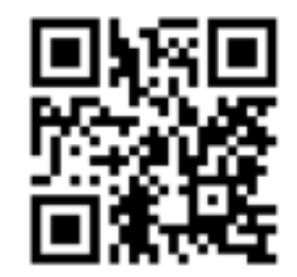

Gambar 1. QR Code

\subsection{Android}

Android adalah sistem operasi seluler yang dikembangkan oleh Google. Ini didasarkan pada versi modifikasi dari kernel Linux dan perangkat lunak open source lainnya, dan dirancang terutama untuk perangkat seluler layar sentuh seperti smartphone dan tablet. Selain itu, Google telah mengembangkan TV Android untuk televisi, Android Auto untuk mobil, dan Wear OS untuk perangkat yang dapat dikenakan pada smartwatch, masing-masing dengan antarmuka pengguna khusus. Varian Android juga digunakan pada konsol game, kamera digital, PC, dan elektronik lainnya. Awalnya dikembangkan oleh Android Inc., yang dibeli Google pada 2005, Android diluncurkan pada 2007, dengan perangkat Android komersial pertama diluncurkan pada September 2008. Versi stabil saat ini adalah Android 10 , dirilis pada 3 September 2019. Inti kode sumber Android dikenal sebagai Android Open Source Project (AOSP), yang terutama dilisensikan di bawah Lisensi Apache ("Android (operating system), , 2019).

\subsection{MIT App Inventor}

App Inventor adalah aplikasi web sumber terbuka yang awalnya dikembangkan oleh Google, dan saat ini dikelola oleh Massachusetts Institute of Technology (MIT) (“App Inventor," 2018). Adalah sebuah tool untuk membuat aplikasi android, yang memudahkan dari tool ini adalah karena berbasis visual block programming, jadi kita bisa membuat aplikasi tanpa kode satupun. Disebut visual block programming, karena kita akan melihat, menggunakan, menyusun dan drag-drops block yang merupakan simbol-simbol perintah dan fungsi tertentu dalam membuat aplikasi, secara sederhana kita bisa menyebutnya tanpa menuliskan kode program. 


\subsection{Google Sheet}

Merupakan aplikasi office berbasis web dan penyimpanan data secara gratis. Google Sheet memiliki kegunaan dan fitur yang hampir sama dengan MS Excel. Produk google ini memperbolehkan pengguna untuk menyimpan, membuat, mengedit, membagikan, menganalisis, melacak perubahan dokumen online dan dapat berkolaborasi dengan pengguna lain secara realtime (S. Gunter and P. Rutledge, 2014).

\subsection{Google Apps Script}

Adalah platform pengkodean program untuk pengembangan aplikasi ringan pada platform Google. Dasar bahasa pemrograman menggunakan JavaScript 1.6, tetapi beberapa bagian mencakup versi 1.7 dan 1.8 serta ECMAScript 5 API. Apps Script menyediakan cara mudah untuk mengotomatiskan tugas di seluruh produk Google dan layanan pihak ketiga serta alat yang mendukung add-on untuk Google Docs, Sheet, dan Slide ("Google Apps Script," 2019).

\subsection{Google Sites}

Digunakan untuk membuat situs web pribadi maupun kelompok, untuk keperluan personal maupun korporat atau umum (J. Beswick, 2009). Google Sites adalah cara termudah untuk membuat informasi dapat diakses oleh orang yang membutuhkan cepat, dan orang-orang dapat bekerja sama dalam situs untuk menambahkan berkas file lampiran serta informasi dari aplikasi Google lainnya seperti Google docs, sheet, forms, calender dll.

\section{Metode Penelitian}

\subsection{Pengumpulan Data}

a. Observasi

Analis sistem melakukan pengamatan langsung di SMA Negeri 17 Surabaya dan melakukan pencatatan secara sistematik terhadap unsur-unsur yang diteliti, khususnya mengenai sistem pencatatan data presensi siswa.

b. Wawancara

Tahapan ini dilakukan pertemuan dengan sesi tanya jawab kepada narasumber yaitu guru dan siswa di SMA Negeri 17 Surabaya sebagai bahan untuk membantu memahami lebih jelas tentang sistem yang sudah berjalan dan yang akan dibuat serta dokumen atau file sebagai data dasar.

\subsection{Analisis Kebutuhan}

Analisis kebutuhan sangat diperlukan dalam mendukung kerja sistem, dimana beberapa kebutuhan dalam sistem yang digunakan untuk membantu jalannya proses pembuatan sistem. Dibagian ini akan dibagi menjadi dua bagian yaitu kebutuhan fungsional dan kebutuhan non fungsional.

1. Kebutuhan Fungsional

Adalah analisa mengenai fitur apa saja yang akan di terapkan pada aplikasi presensi siswa menggunakan QR Code ini, fitur tersebut antara lain :
a. Menambah, merubah, dan menghapus data siswa
b. Melakukan presensi dengan menscan QR Code pada kartu pelajar/presensi siswa
c. Mengetahui siswa yang hadir atau tidak pada hari tersebut
d. Melihat rekap kehadiran, telat, sakit, izin, alpha per semester ganjil, genap dan tahun

2. Kebutuhan Non Fungsional
a. Koneksi internet
b. Hardware dan OS : Smartphone Android dan Laptop/PC (Windows, Linux, Mac OS)
c. Browser Chrome, Edge, Mozilla, Opera
d. Akun google free atau premium 


\section{Hasil dan Pembahasan}

\subsection{Arsitektur Aplikasi}

Pada gambar 2 dibawah menjelaskan arsitektur dan alur sistem dari aplikasi presensi, input kehadiran dimulai dari siswa datang ke sekolah, MIT App Inventor dan Google Script mengambil data siswa dengan scanner dan mengirimkan ke Google Sheet melalui jaringan internet, data diproses dalam Google Sheet dan output menampilkan hasil rekap kehadiran dengan Google Site untuk guru serta wali murid yang bisa digunakan lebih lanjut untuk keperluan lainnya.

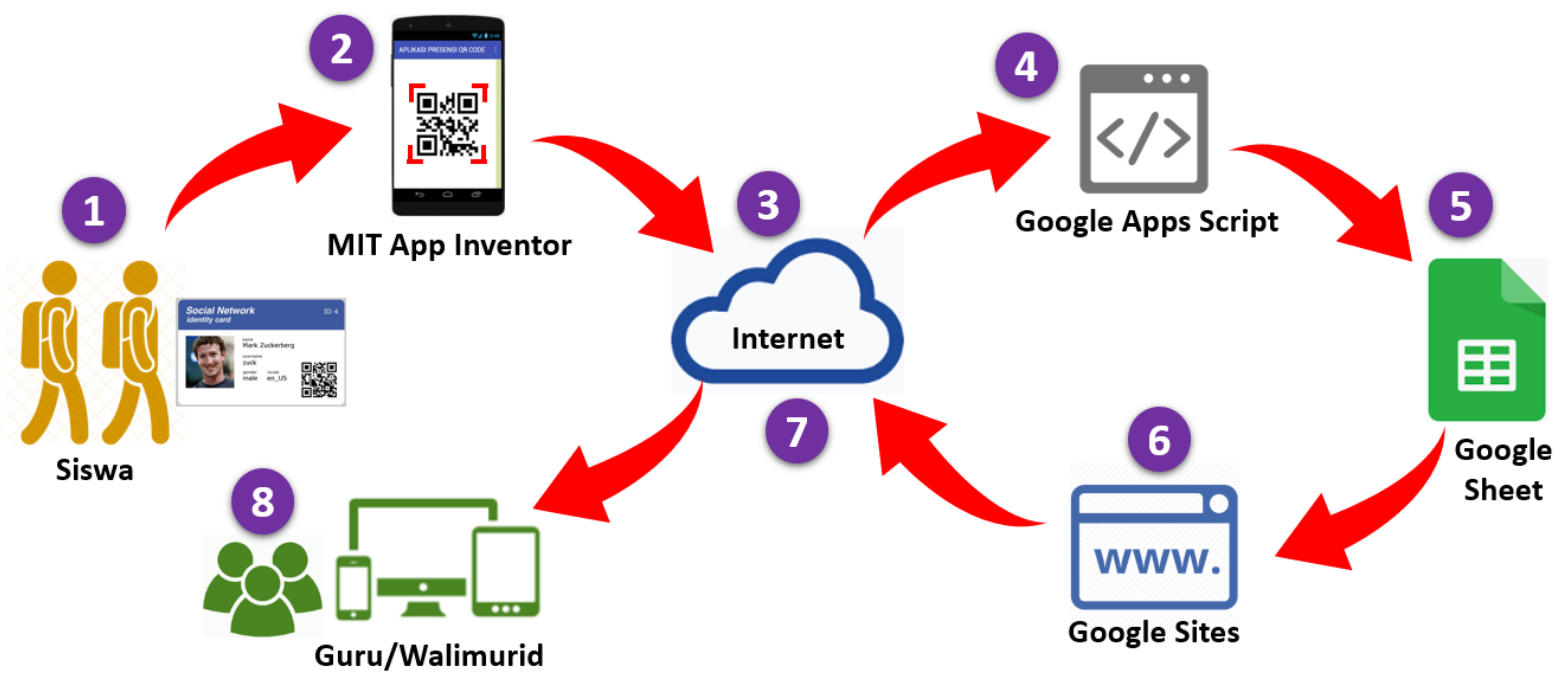

Gambar 2. Arsitektur Aplikasi

\subsection{Implementasi}
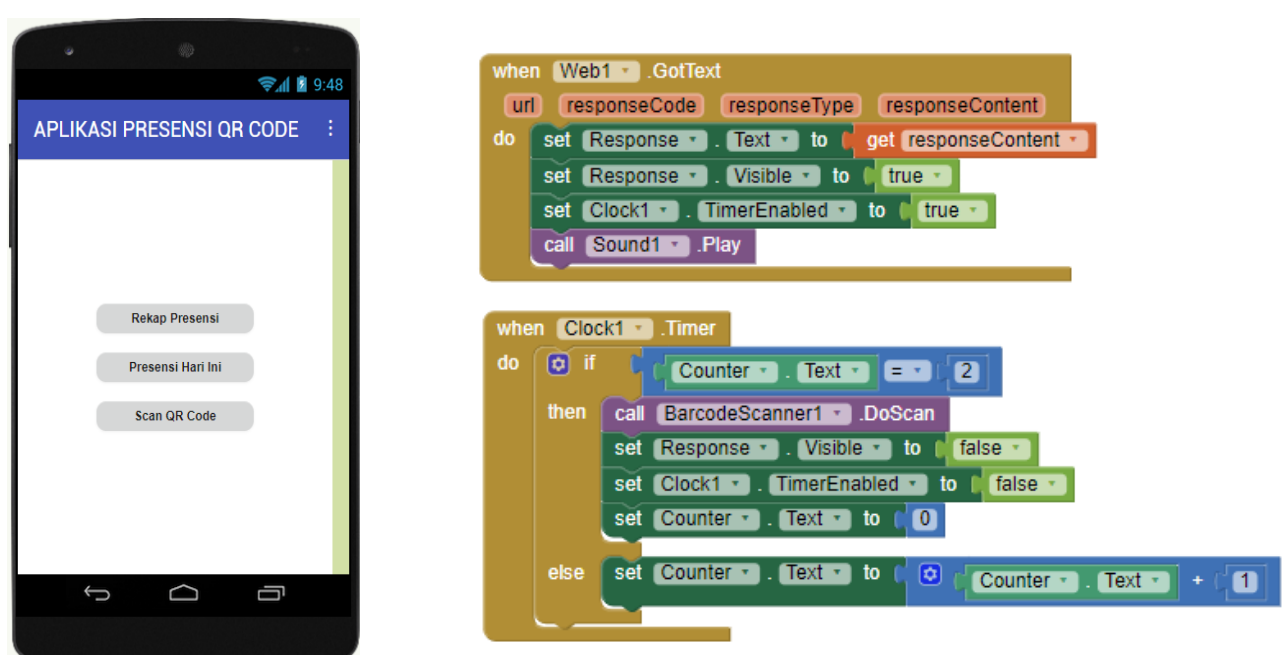

Gambar 3. Tampilan di Android dan blok kode

Gambar diatas adalah tampilan aplikasi setelah dilakukan instalasi pada perangkat android, dan beberapa potong blok kode pada App Invetor. Terdapat 3 pilihan menu, Rekap Presensi, Presensi Hari Ini, dan Scan QR Code. Menu Rekap Presensi, digunakan untuk melihat rekap kehadiran, telat, sakit, izin, alpha per semester ganjil, genap dan tahun. Menu Presensi Hari Ini, digunakan untuk mengetahui siswa yang hadir atau tidak pada hari tersebut. Menu Scan QR Code, digunakan untuk melakukan presensi dengan menscan QR Code pada kartu pelajar/presensi siswa. 


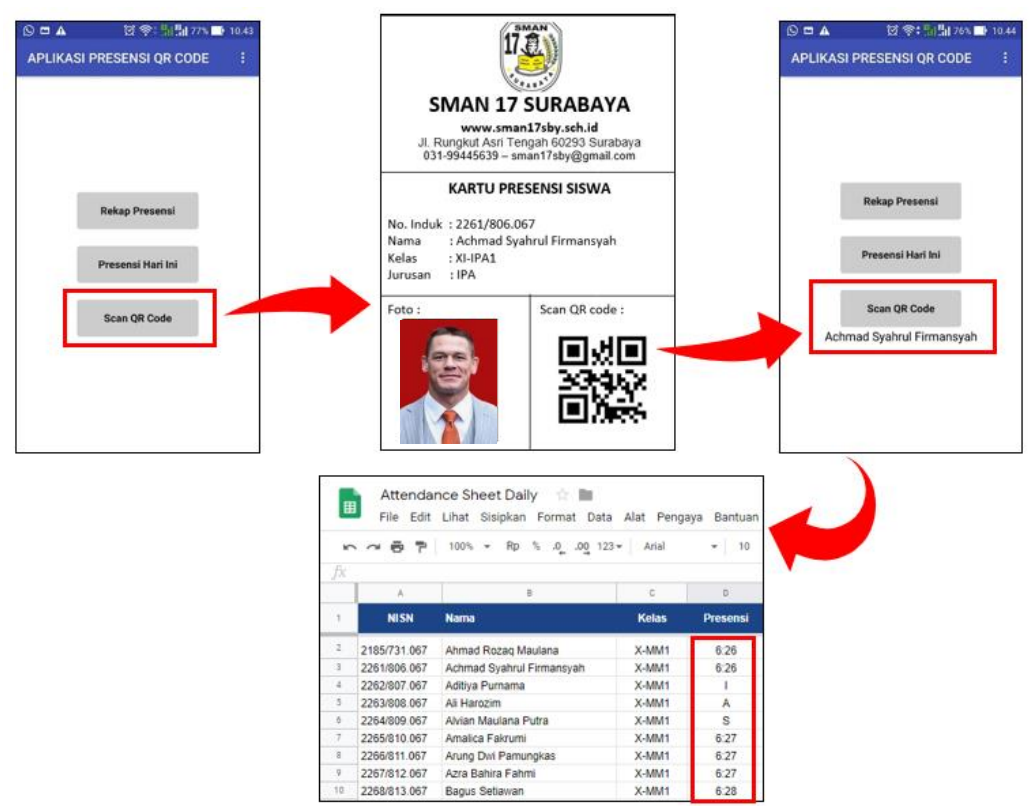

Gambar 4. Proses Scan QR Code kehadiran

Tampilan gambar 4 menjelaskan input data waktu kehadiran tiap siswa setiap hari yang akan dikirim dan disimpan kedalam Google Sheet presensi harian, jika tidak hadir karena sakit, izin, dan alpha atau tanpa keterangan harus diinput langsung kedalam sheet menggunakan laptop dengan browser Chrome atau Mozilla, ketentuan inisial input sebagai berikut : S = Sakit, I = Izin, A = Alpha.

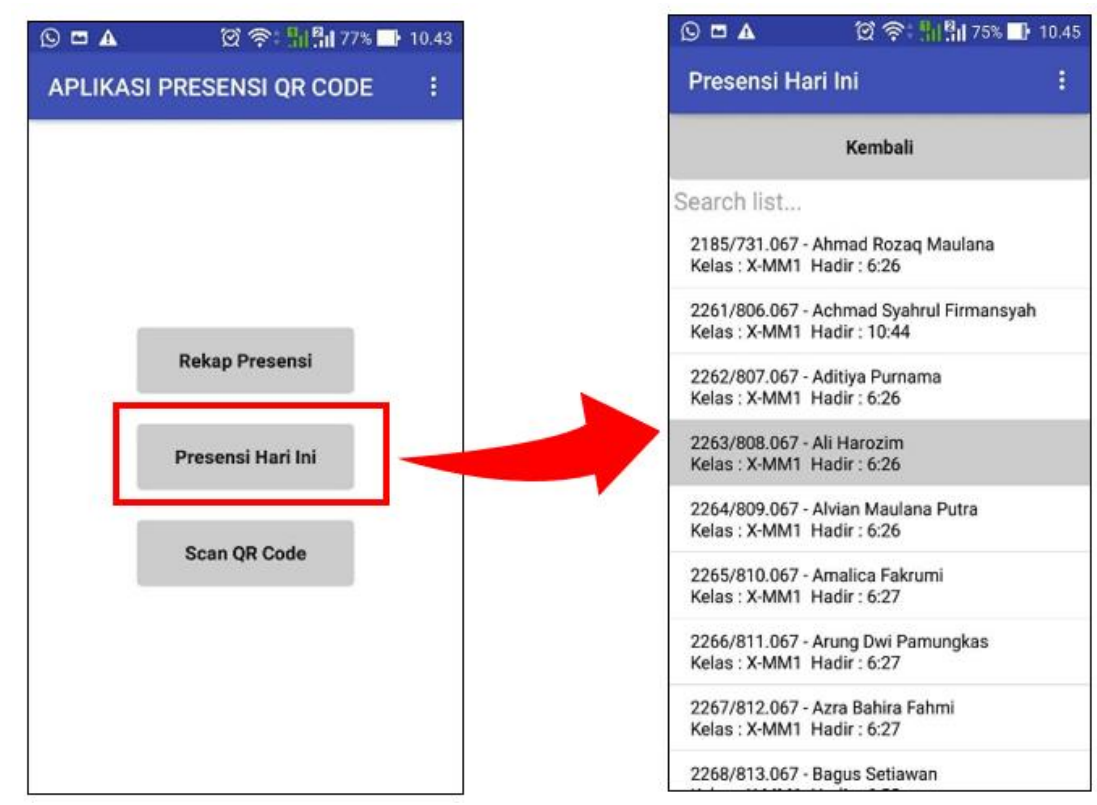

Gambar 5. Menu Presensi Hari Ini

Pada gambar diatas, digunakan untuk melihat hasil presensi siswa yang sudah melakukan scan QR Code dan yang belum pada hari ini yang sedang berjalan, akan tampil waktu masuk setiap siswa dan fungsi pencarian berdasarkan kelas atau nama siswa. 


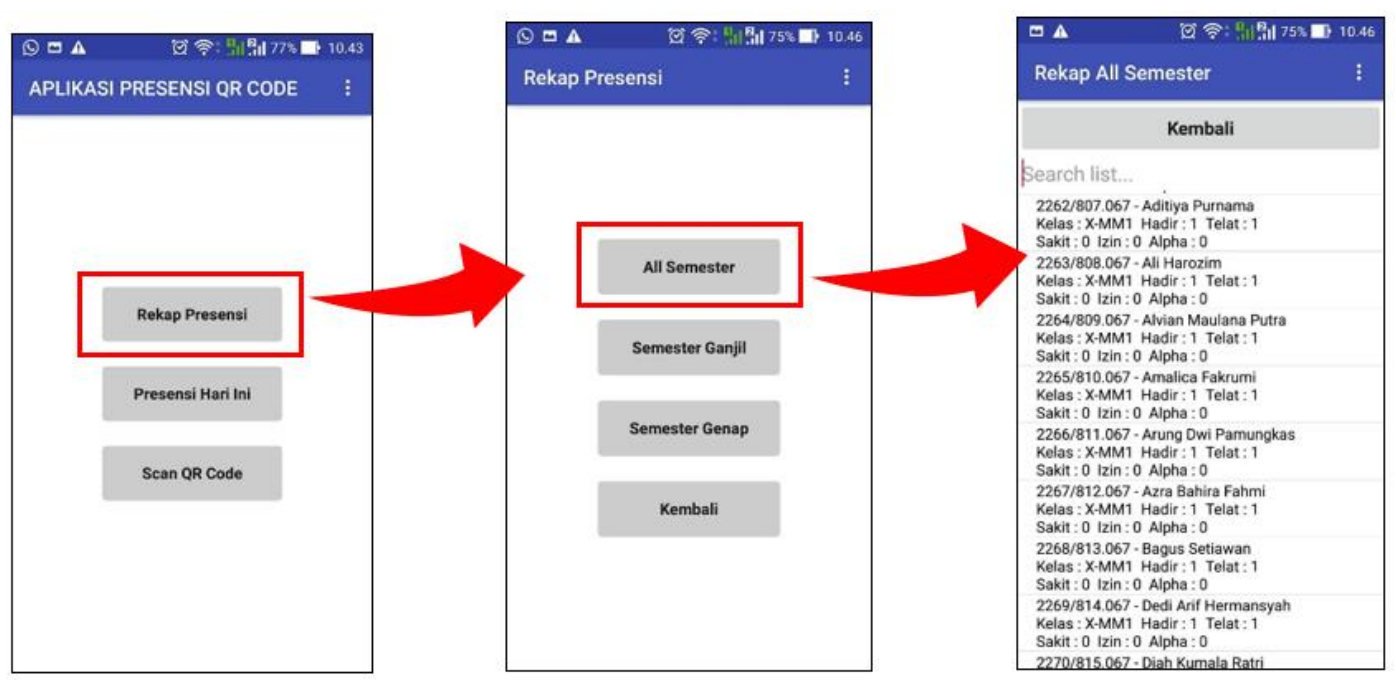

Gambar 6. Menu Rekap Presensi

Pada tampilan gambar 6 digunakan untuk melihat hasil rekap presensi semester ganjil, semester genap dan all semester atau tahun, akan tampil total hadir, sakit, izin dan alpha dari setiap siswa.

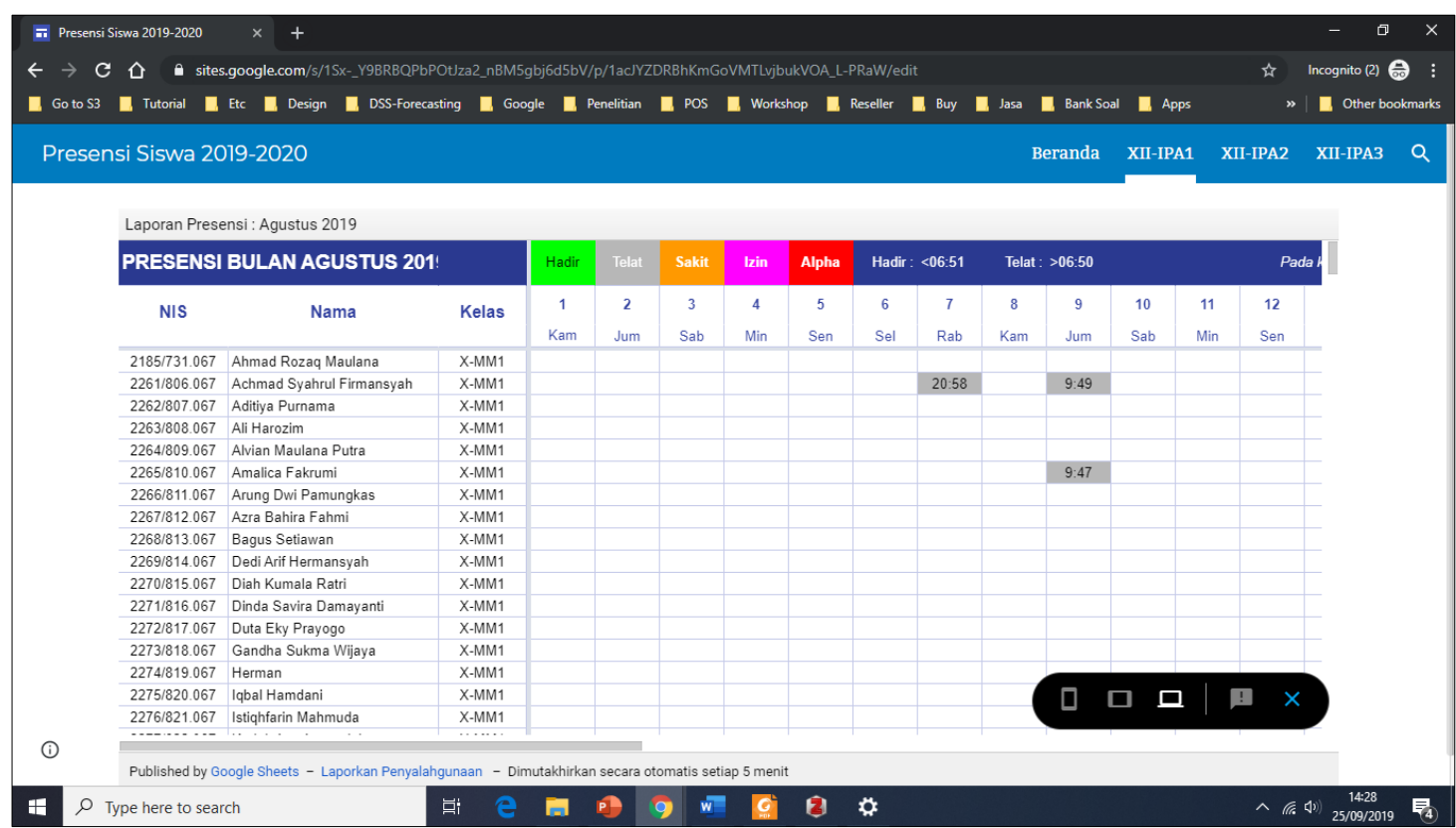

Gambar 7. Tampilan Rekap Presensi dengan Google Sites

Gambar diatas adalah tampilan hasil input presensi siswa melalui smartphone android dan QR Code, kemudian disimpan kedalam Google Sheet dan direkap dengan formula sederhana serta ditampilkan lewat browser menggunakan Google Sites yang bisa dibuka dengan browser Chrome atau browser yang lain. Untuk wali murid bisa melihat rekap kehadiran lewat tampilan Google site ini.

\subsection{Skenario Presensi}

- Siswa datang ke sekolah, melakukan presensi scan QR Code yang ada pada kartu pelajar atau Id card menggunakan smartphone/tablet milik guru atau milik sekolah yang disediakan khusus. 
- Petugas atau guru yang melakukan scanning bisa lebih dari satu untuk mengurangi antrian. Cara lain, smartphone/tablet dipasang pada tripod dan setiap siswa melakukan scanning kehadiran sendiri bergantian.

- Jika ada siswa yang tidak hadir karena sakit, izin, dan alpha atau tanpa keterangan harus diinput langsung oleh petugas atau guru kedalam Google Sheet, ketentuan inisial input sebagai berikut : $\mathrm{S}=$ Sakit $\quad \mathrm{I}=$ Izin $\quad \mathrm{A}=$ Alpha

- Semua guru yang ada di kelas bisa melihat hasil presensi sebelum memulai pelajaran atau melakukan tindakan untuk siswa yang terlambat.

- Wali murid, bimbingan konseling atau guru bisa melihat rekap harian, semester, dan tahun menggunakan laptop dengan browser untuk melakukan tindakan lanjutan jika ada siswa yang sering tidak hadir melebihi batas aturan yang ditentukan oleh sekolah.

\section{Kesimpulan}

Dari hasil selama proses pengumpulan data, analisis kebutuhan, pemodelan arsitektur dan implementasi dapat diambil kesimpulan sebagai berikut :

a. Aplikasi berhasil dibangun menggunakan produk-produk Google yang bisa digunakan secara gratis seperti Google Sheet, Google Apps Script, Google Sites, MIT App Inventor, dan Android.

b. Aplikasi yang dibangun berhasil melakukan scan QR Code presensi dan merekap secara otomatis, sehingga evaluasi kedisiplinan siswa menjadi lebih mudah.

c. Sistem yang dibuat dapat mempermudah Guru atau bimbingan konseling mengevaluasi siswa sebagai salah satu komponen penilaian yang bisa menentukan siswa naik ke tingkat berikutnya dan wali murid juga bisa mengawasi kehadiran anaknya.

\section{Referensi}

Android (operating system), 2019. . Wikipedia.

App Inventor, 2018. . Wikipedia bahasa Indonesia, ensiklopedia bebas.

Ching-yin law, Simon so, 2010. QR Codes in Education. Journal of Educationan Technology

Development and Exchange 3, 85-100.

Google Apps Script, 2019. . Wikipedia.

I. Cahyani, 2016. Adopsi Google Apps For Education Di Perguruan Tinggi : Sebuah Kolaborasi Real-

Time Dosen Dan Mahasiswa. Jurnal PPKP 19, 183-202.

J. Beswick, 2009. Getting Productive With Google Apps, 1st ed. ed. 415 System Inc.

Rachman Arief, 2017. Aplikasi Presensi Siswa Online Menggunakan Google Forms, Sheet, Sites,

Awesome Table Dan Gmail. Presented at the SNTEKPAN V, ITATS, Surabaya, pp. 137-143.

S. Gunter, P. Rutledge, 2014. My Google Apps. Que, Indianapolis. 